\title{
Dziwna wycieczka do zoo. W poszukiwaniu perspektywy
}

\section{The strange trip to the zoo. In the search of another perspective}

\author{
||Joanna Żygowska
}

\begin{abstract}
The article tries to analyze children's poems by Józef Ratajczak, in which there are animals in a zoo (from author's poetry volumes Między nami zwierzakami and Wycieczka do zoo). Reading Ratajczak's chosen works let us notice different ways of describing by the poet both animals and zoo. The article also poses the question of an adult writer who writes for children. The article helps us see what connects children and animals in a variety of literary texts - their voice always depends on imagination of adults.
\end{abstract}

Key words: Józef Ratajczak, poetry for children, zoo, child, animal

Streszczenie: Artykuł jest próbą spojrzenia na wiersze dla dzieci Józefa Ratajczaka, w których pojawiają się zwierzęta w zoo (z tomików Między nami zwierzakami oraz Wycieczka do zoo). Lektura wybranych utworów pozwala zauważyć różny sposób postrzegania przez poetę zwierzęcych bohaterów oraz miejsca, jakim jest zoo. W artykule zostało także postawione pytanie o dorosłego nadawcę tekstu literackiego kierowanego do dziecka. Pozwala to zauważyć to, co łączy dzieci i zwierzęta w tekstach - ich głos zawsze jest zależny od wyobrażenia tego, kto mówi, od osoby dorosłej.

Słowa kluczowe: Józef Ratajczak, poezja dla dzieci, zoo, ogród zoologiczny, dziecko, zwierzę

\section{Dzieci i zwierzęta}

Zwierzęta są obecne w literaturze dla dzieci, w ogóle w sztuce, kulturze i popkulturze dziecięcej. Interesują jej twórców jako przedstawiciele konkretnych gatunków, w formie zinfantylizowanej - jako zabawki, lub w fantastycznej - w postaci wymyślonych stworów. Genezy tego zjawiska można szukać już w tekstach kultury, które pierwotnie nie były dedykowane młodym odbiorcom - w bajkach (począwszy od Ezopa), baśniach i legendach. Występują jako alegorie, więc i pouczają, bawią, śmieszą oraz pomagają wzbudzać empatię. Pod piórami poszczególnych autorów są obecne na różnych zasadach. Zaryzykuję stwierdzenie, że zwierzęta w literaturze dla 
dzieci to temat, którego w jednej pracy nie dałoby się opisać w sposób zupełnie kompletny, warto jednak przyglądać się poszczególnym problemom.

Mój szkic dotyczy dwóch tomików z wierszami dla dzieci - Józefa Ratajczaka Między nami zwierzakami (1971) oraz Wycieczka do zoo $(1982)^{1}$. Choć wspominam obie książki, przede wszystkim interesuje mnie ta późniejsza. Zwracam jednak uwagę także na pierwszą, ponieważ część opublikowanych tam wierszy przedrukowana została jedenaście lat później w nieco zmienionej wersji. Będę się powoływać przede wszystkim na Wycieczkę do zoo, a w uzasadnionych przypadkach sięgnę także po Między nami zwierzakami².

Nie są to jedyne miejsca w twórczości tego poety, w których pojawiają się zwierzęcy bohaterowie. Samym kotom został poświęcony Wlazł kotek na płotek (1990). O zwierzętach traktują także utwory umieszczone w innych książkach Ratajczaka, na przykład Wiatr-ptak (Zamki na lodzie, 1966), Gil (Pokój z kukułka, 1967) czy Niedźwiedź i muzyka (Zima w oknie, 1967). Na tym etapie rozpoznania ograniczam się tylko do dwóch tomów, ponieważ chciałabym zwrócić uwagę na sposób prezentacji zwierząt, z woli i władzy człowieka, zamieszkujących zoo. Skupię się także na ich relacji z dzieckiem oraz na sposobie przedstawienia dziecięcej perspektywy przez dorosłego autora. Interesuje mnie także możliwość czytania książki poetyckiej dla dzieci jako świadomie konstruowanej i zatytułowanej całości (nie tylko zbioru czy wyboru).

Obecności zwierząt w poezji dla dzieci Ratajczaka obszerne fragmenty poświęciła Zofia Ożóg-Winiarska w książce Poezja dla dzieci Józefa Ratajczaka z 2005 roku. Autorka stworzyła swoisty katalog zwierząt, pojawiających się w tej twórczości, a każde z nich opatrzyła krótką charakterystyką, czasami rozszerzoną o kulturowe znaczenie poszczególnych gatunków.

Sposób przedstawienia zwierząt, ich relacji z dzieckiem, a także samych dzieci, w sztuce dla młodych odbiorców nie jest tożsame z ich perspektywą, ale wynika z wyobraźni i wyobrażeń na ten temat pochodzących od piszącej osoby dorosłej. Może właśnie to spojrzenie i pytanie, w jakim stosunku do czytelnika znajduje się nadawca komunikatu artystycznego, najbardziej różni literaturę dla dzieci i dla dorosłych. Dorosły z racji wieku ma władzę nad dzieckiem, między innymi dlatego, że włada słowem pisanym. Dziecko tylko (czy tylko?) czyta, ogląda lub słucha. Siła tej władzy jest sprawą indywidualną, zależną od poszczególnych autorów i autorek. To właśnie ich talent, wrażliwość i empatia warunkują to, jak blisko odbiorcy znajdzie się tekst³ . Dziecko może tylko (aż!) podważać wiarygodność komunikatu

\footnotetext{
Biorąc pod uwagę datę publikacji tomiku (1982), poszczególne wiersze można odczytywać także niedosłownie, jako język ezopowy. Wtedy też, w kontekście ówczesnej sytuacji politycznej - stanu wojennego, zamiast zwierząt, kreślone scenki rodzajowe dotyczyłyby ludzi zniewolonych mentalnie lub uwięzionych dosłownie.

Wiersze Józefa Ratajczaka cytuję za wydaniem Wycieczka do zoo, Poznań 1982.

Wstępną refleksję związaną z relacją tekstu i dziecka, a także autora i jego czytelnika, w tym kontekście podjął już Ryszard Waksmund w artykule Od poezji dydaktycznej do liryki dziecięcej z tomu Poezja dla dzieci. Mity i wartości, 1986, Zurakowski B. (red.), Warszawa, później w książce Od literatury dla dzieci do literatury dziecięcej, 2000, Wrocław. Poezję dla dzieci podzielił tam na:
} 
artystycznego, kontestować go, nudzić się albo zupełnie odwrotnie - podejmować grę z autorem lub całkowicie uwierzyć kreowanym światom.

$\mathrm{O}$ analogii w postrzeganiu dzieci i zwierząt w perspektywie animal studies i literatury dla młodych czytelników pisali Ewelina Rąbkowska i Maciej Skowera w artykułach opublikowanych w książce Czytanie menażerii Zwierzęta $w$ literaturze dziecięcej, młodzieżowej i fantastycznej ${ }^{4}$, powołując się na wcześniejsze badania z tego obszaru.

Autorka pokazuje analogię między trash animal (śmieciowe zwierzęta ${ }^{5}$ ), kategorią obecną na gruncie trash studiem, a polskim sformułowaniem „dzieci śmieci”. Rąbkowska zwraca uwagę na dwa aspekty wskazanego problemu. Pierwszy to (antysystemowy) brud przypisywany bezużytecznym zwierzętom, ale także dzieciom. Drugi - wolność i nieposłuszeństwo, jakie wiążą się ze stanem dzieciństwa, ale i z byciem zwierzęciem. Autorka omawia utwory dla dzieci i młodzieży (Ośla Skórkę Charles’a Perraulta, Pinokia Carla Collodiego oraz Szczury i wilki Grzegorza Gortata) i pokazuje, że „w chwilach kryzysu dziecko jest szczególnie bliskie zwierzęciu znajdującemu się w opresji” (Rąbkowska 2016, 36).

O dziecku i zwierzęciu jako o istotach poddanych władzy dorosłych wspomniał także John Berger w eseju Po cóż patrzeć na zwierzęta?. Przed pojawieniem się silnika spalinowego, zwierzęta, ale także właśnie dzieci, służyły jako podstawowe maszyny do pracy (Berger 1999, 19). Sytuacja ta dzisiaj zmieniła się tylko częściowo, współcześnie i dzieci, i zwierzęta wciąż w różnych rejonach świata są wykorzystywane w tym celu.

Maciej Skowera już w tytule artykułu - Literackie spotkania istot podporzadkowanych. Studium przypadku: Miasteczko ostatnich westchnień, zwraca uwagę na stan, który zbliża dzieci i zwierzęta - podporządkowanie. To także powód, dla którego można mówić o punktach zbliżających do siebie animal studies i children studies. Badacz powołuje się na rozpoznania

wiersze dla dzieci, lirykę dla dzieci, wiersze dziecięce, lirykę dziecięca (s. 157-170). Istotne było dla niego, czy utwór jest kierowany do dziecka, czy próbuje szukać z nim relacji. Przemyślenia na ten temat zapisał także Józef Ratajczak, m.in. w tekście Rewolucja przyimków, opublikowanym na łamach „Sztuki dla Dziecka” (1986, nr 1, s. 26-27). Ta refleksja, jak i pozostałe teksty powstałe w ramach cyklu felietonów publikowanych pod hasłem $Z$ dzieckiem $w$ herbie, są o tyle ciekawe, że mają swoje źródło w doświadczeniach osoby piszącej dla dzieci, chcącej rozumieć swojego odbiorcę i się do niego przybliżać. Nie znaczy to jednak, że wszystkie utwory, z dzisiejszej perspektywy, czytamy jako teksty rzeczywiście poszukujące głosu i spojrzenia dziecka. To jednak temat trudny i pełen pułapek. Przed blagą związaną ze znajomością przez dorosłego duszy dziecka przestrzegał już w 1955 Jan Brzechwa na łamach „Twórczości”, do czego także nawiązał autor Ziarenek maku.

Mik A., Pokora P., Skowera M. (red.), 2016, Czytanie menażerii. Zwierzęta $w$ literaturze dziecięcej, młodzieżowej i fantastycznej, Warszawa. Już na samym początku zwraca uwagę tytuł publikacji (a także konferencji, która odbyła się wiosną 2015 roku z inicjatywy Koła Baśni, Literatury Dziecięcej i Młodzieżowej i Fantastyki Uniwersytetu Warszawskiego) - obecne w nim słowo „menażeria”. Menażerie, które zyskały popularność w Europie w XVIII wieku, poprzedniczki dzisiejszych ogrodów zoologicznych, były symbolem władzy i bogactwa królewskiego lub arystokratycznego dworu. To także obraz panowania człowieka nad światem natury (Świtek 2007, 11-13). Ta notatka na marginesie oczywiście nie odbiera wartości wspomnianych tekstów. Na okładce książki znajduje się także grafika, która metaforycznie pokazuje sytuację zwierząt w kulturze dziecięcej. W sylwetkę niedźwiedzia wpisany jest także, między przednimi łapami, kontur pluszowego misia. W dziecięcym świecie, kreowanym przez dorosłych, niedźwiedź często jest sprowadzany do roli misia, dalej - pluszaka. A pluszowy miś stanowi metonimię zabawki.

"<<Śmieciowość $>>$ zwierząt definiowana jest jako zbiór takich cech, jak: inwazyjność, nadliczbowość, bezwartościowość dla człowieka, nawet odrażający wygląd. Tę kategorię odnosi się często (na terenie USA) do szczurów, karpi, gęsi, psów czy gołębi" (Rąbkowska 2016, 34). 
Karoliny Szymborskiej z tekstu W laboratorium „children studies”. Dziecko i dzieciństwo $w$ nowym dyskursie. Autorka pisze, że inaczej niż w przypadku studiów nad kobietami i studiów etnicznych (gdzie także istotne jest analizowanie relacji władzy) w badaniach nad zwierzętami mamy do czynienia z istotami, które nie mogą mówić własnym głosem (Szymborska $2014,185)$. Skowera buduje trafną analogię, z zastrzeżeniem dotyczącym uwzględnienia koniecznych różnic między posthumanistyczną refleksją nad zwierzętami oraz dzieckiem i dzieciństwem (Skowera 2016, 55).

Rąbkowska wspomina także, że ważna dla badań nad dzieciństwem okazuje się pedagogika Korczakowska z przełomu XIX i XX wieku, uznająca podmiotowość dziecka takim, jakim jest ono na każdym etapie rozwoju. Stary Doktor korzystał z analogii dziecka i zwierzęcia, jednak nie po to, by pokazać negatywnie nacechowaną w kulturze zwierzęcość (niegotowość, bliskość natury) młodego człowieka, jak czyniono to wcześniej. Badaczka pisała:

inną sprawą jest, że polski pisarz i pedagog przypisywał dziecku niezwykłą wrażliwość na zwierzęcy los. Rozumie on bowiem, że niejako podziela dolę i status zwierząt $\mathrm{w}$ świecie dorosłych, i że jest to solidarność niewolników - istot słabszych. Tylko w tym sensie w odniesieniu do pism Korczaka można mówić o bliskości dziecka i zwierzęcia (Rąbkowska 2016, 33).

O uwzględnianiu wrażliwości dziecka na sytuację zwierząt, zwierząt w sytuacji szczególnej (i - bardzo powszechnej) niewoli w zoo, można mówić także w przypadku niektórych wierszy Ratajczaka. Ujęcie to nie jest jednak pozbawione rys (śladów dorosłej perspektywy?). To także pytanie o punkt widzenia poety stającego wobec zwierzęcia. Ów poeta, „autor tej książeczki", słucha wypowiedzi dzieci odwiedzających zoo w wierszu pt. Co powiedziały dzieci autorowi tej książeczki, utworze zamykającym Wycieczkę do zoo. Wiersz może posłużyć za soczewkę, w której widzimy empatyczny - choć niepozbawiony pewnej skazy - stosunek dzieci, opisywanych przez poetę, do zwierząt w zoo. Ilustrują to już dwa fragmenty tego stosunkowo długiego utworu:

Dla dzięcioła

trzeba zaraz poszukać

kilka próchniejących drzew.

I teraz ptaka przywołać.

Niech je dobrze opuka.

Słyszycie?

To nie pukanie,

to śpiew.

(...)

Bo motyl jest najwspanialszym motylem

właśnie na łące pachnącej,

myszka jest najprawdziwszą myszką,

gdy widzisz ją tylko przez chwilę,

nim zniknie w swojej norce, 
a słowik staje się królem słowików,

kiedy przez całą noc śpiewa

ukryty w koronie drzewa,

tak pięknie, że słów brak w słowniku.

Sprowadźmy więc dla wielbłąda

afrykańskie słońce.

Wtedy dopiero będzie wyglądał

na stuprocentowego wielbłąda,

co przemierza pustynię

bez końca.

(...)

Kiedy dżunglę sprowadzą

dla małp

i dla tygrysa?

I czy niedźwiedziom Karpat

nie można oddać

już

dzisiaj?

Głos dziecka kreowany przez autora (a zarazem głos samego poety?) sygnalizuje wrażliwość na los istot zamkniętych w zoo. Wyrazem tego jest przekonanie, że zwierzę powinno żyć w naturalnych dla siebie warunkach, w przestrzeni, w której może poszukiwać domu. Takie myślenie przedstawione $\mathrm{w}$ pierwszych strofach zostaje nieco zaburzone w kolejnych, gdy pojawia się sugestia zastosowania półśrodka, bez naruszania istniejącego porządku. Najbardziej wyraźnie jest to widoczne w części dotyczącej wielbłąda. Pojawia się sugestia, jakoby odpowiednie warunki życia dla zwierzęcia można było stworzyć, eksportując odpowiednie elementy krajobrazu, nie zaś pozwalając żyć mu w miejscu, gdzie są one naturalne.

Czy wobec tego rzeczywiście możemy mówić o obecności głosu dziecka wrażliwego na los zwierząt? Prawdopodobnie w obu przypadkach i w utworze Ratajczaka, i w moim komentarzu - mamy do czynienia z kulturowym konstruktem i z dorosłym wyobrażeniem na temat dziecięcej perspektywy. Nie da się zaprzeczyć, że sposób widzenia świata przez małego człowieka jest związany nie tylko z piękną, intuicyjną empatią, ale odbiją się w nim także przekonania bliskich mu dorosłych. To wszystko składa się na naturalny chaos, w którym funkcjonuje dziecko. Nieoczywisty wiersz Ratajczaka dotyczy nie tylko samego zoo, ale można go odczytać także jako próbę zobrazowania głosu dziecka w literaturze. Wiersze, które taką próbę podejmują, w wielu przypadkach są nasycone uwrażliwieniem na los innych istot. Jednak często, chyba ze względu na chęć rozśmieszenia odbiorcy, zwierzęta są $\mathrm{w}$ nich przedstawione z perspektywy antroponormatywnej. Wtedy wartością jest to, co ludzkie (np. postawa, ubiór), a cechy typowo zwierzęce - problemem, czasami wręcz anomalią. 


\section{Kto prowadzi dzieci do zoo?}

Znacząca różnica zasygnalizowana $\mathrm{w}$ tytułach interesujących mnie tomików Między nami zwierzakami a Wycieczka do zoo nie została już tak konkretnie wykorzystana w samej treści książek. Pierwszy sugeruje, że zwierzęta zostaną przedstawione $\mathrm{w}$ ich świecie, drugi - w sytuacji zniewolenia, jako atrakcje w zoo. Jednak już tytułowe „zwierzaki”, nie „zwierzęta”, odwołują się do perspektywy ludzkiej, odrobinę pobłażliwej. „Zwierzak” prowadzi wyobraźnię w nieco inną stronę niż „zwierzę”. Tu dodatkowo pojawia się także rym, który już na samym początku spełnia oczekiwania - dorosłe wyobrażenie na temat wierszy dla dzieci. Antropocentryczny i "dorosły” punkt widzenia obciąża spojrzenie poety. Nie znaczy to jednak, że całkowicie brak mu wrażliwości zarówno na małego człowieka, jak i przedstawicieli pozaludzkich gatunków.

Nasuwa się pytanie: kto prowadzi dzieci do zoo (analogicznie można zapytać także o cyrk). Odpowiedź nie jest skomplikowana - rodzice, dziadkowie, nauczyciele. Już od wczesnego dzieciństwa, od przedszkola. Zoo, obecne w większości dużych miast, stanowi obowiązkowy punkt wycieczek i uatrakcyjnia niedzielne popołudnia. Oczywiście, wiąże się to także z oczekiwaniami i marzeniami samych dzieci. Jednak ich wyobrażenie na ten temat od początku nie jest samodzielne, niejako wynika z przekonań dorosłych. Ich perspektywa dominuje i tworzy opinię, nim młody człowiek sam będzie miał szansę doświadczyć spaceru między klatkami, akwariami i wybiegami zwierząt, które nie są tak urocze jak te z obrazków i przedstawień w formie zabawki. Dowie się jeszcze w domu, przed wyjściem, „jak patrzeć na zwierzęta". Taka wycieczka do zoo może jednak przynieść rozczarowanie. Żywe zwierzę, któremu odebrano wolność, nie musi spełnić dziecięcych wyobrażeń. Jest ospałe, nie reaguje (zgodnie z oczekiwaniami), nie jest tak "słodkie" (Berger 1999, 32) jak postacie w mainstreamowych animacjach.

Rzeczywistość zoo niewiele ma wspólnego z naturalnymi warunkami, w jakich żyją reprezentanci danego gatunku. „Podczas spaceru opiekunowie mogą pokazać kilkadziesiąt różnych gatunków fauny, w książeczce autor ma szansę opisać ssaki, gady i ptaki, których pojawienie się obok siebie uzasadnia tylko jej tytuł. W naturalnym środowisku nie mogłyby się spotkać" (Kostecka 2007, 16). To od dorosłego towarzysza (na nim spoczywa odpowiedzialność) zależy, jak opowiedziane zostanie zoo jako miejsce spotkania tylu rozmaitych gatunków. Tomiki Ratajczaka także są przedziwnym połączeniem wierszy o zwierzętach pochodzących z odległych od siebie stron świata, ale i różnych sposobów pisania o zwierzętach. Czasami jest to próba wyobrażenia sobie poszczególnych mieszkańców zoo, śmieszne anegdoty na ich temat, nawiązanie do stereotypów lub niezwykle popularne w poezji dla dzieci lingwistyczne zabawy.

Dziecko, zabrane na spacer do ogrodu zoologicznego, zostaje wprowadzone do miejsca, w którym w wyraźny sposób manifestuje się władza 
dorosłego człowieka nad światem przyrody. Tam zerwana zostaje relacja gatunku ludzkiego z przyrodą (Berger 1999, 11-12), a jego dominacja została doprowadzona do skrajności. To także reprodukcja relacji podporządkowania pod pozorem troski, a ta w życiu codziennym w różnym stopniu dotyczy także dzieci. Wszystko to służy utrzymaniu antropocentrycznego porządku, który pozwala zamykać zwierzęta w klatkach i uczyć dzieci ich nazw (Kostecka 2007, 18).

Bezpośrednio o spacerze po ogrodzie zoologicznym traktuje także wiersz Wycieczka do zoo otwierający tomik Ratajczaka z 1982 roku:

Co krok

żelazne pręty.

Myślę więc: Nie do wiary!

Czyżby tu właśnie zwierzęta odsiadywały kary?

Za co?

Przez ile lat

mają tak patrzeć

zza krat?

Lis ukradł futro lisie,

no cóż,

ale co ma włożyć dzisiaj,

gdy na dworze mróz?

Wielbłąd się garbi, lecz przecież

z garbu się nie wyleczy!

Słoń potłukł porcelanę

w sklepie,

wilk też się prowadził nie najlepiej.

Tchórz

stchórzył,

jeż się najeżył,

ale kto im powie lub wywróży,

jak postępować

należy?

Nagle żyrafa

kłania się, jak do fotografii

i szepce mi do ucha:

Posłuchaj!

Jeśli znikną kraty, siatki, pręty,

rozbiegną się na wszystkie strony świata

zebrane tu zwierzęta.

Lis do lasu,

wielbłąd na pustynię,

słoń od razu

w puszczy na zawsze zginie,

tchórz stchórzy,

padnie padalec,

Polonistyka. Innowacje

Numer 5, 2017 
jaszczurki od ziemi nie odróżnisz,

a może nie znajdziesz jej wcale.

Wycieczka do ogrodu zoologicznego od samego początku jest nieoczywista. Dzieci czują dziwność sytuacji, zamknięcie zwierząt, ale autor pomaga im znaleźć uzasadnienia (antropocentryczne!) tego faktu. Wszystkie są oparte na stereotypach i ludzkich skojarzeniach związanych ze zwierzętami. Szczególnie niepokojąca jest ostatnia część wiersza, dokładnie jej cztery wersy. Język człowieka obnaża opresyjny stosunek do innych gatunków. Dwuznaczność słowa „zginie” sprawia, że dotyczy ono nie tylko powrotu do naturalnego środowiska życia, ale także kojarzy się ze śmiercią. Czasowniki związane z tchórzem i padalcem mają wydźwięk pejoratywny. W ten sposób, paradoksalnie, takiego charakteru nabierają słowa, które miały mówić o wolności. Poeta, choć nieobca mu empatia, wpada w pułapkę języka. Gry słowne i wieloznaczności okazują się niebezpieczne i obnażają antropocentryczne oko.

O zniewoleniu, o kratach Ratajczak pisał także w odniesieniu do ptaków zamkniętych w klatach, np. w wierszu Klatka z ptakami:

Ile tu zamknięto

przepięknych instrumentów!

Orkiestra z nich

niemała

ugina niebo jak gałąź

i gra - bez dyrygenta.

Próba przedstawienia zachwytu ptasią muzyką zostaje jednak zaburzona. Ta pieśń jest pieśnią niewolników. Ptaki znajdują się w klatce, instrumenty zostały „zamknięte”. Metafora ptaków jako instrumentów, choć nośna, uprzedmiotawia zwierzę, sprowadzając do jednej funkcji. Niemniej oglądanie ich w zoo i zachwycanie się ich głosami nie może być niewinne. Tytuł można odczytać także jako grę z frazeologizmem „ptaszek w klatce”. Jednak zmiany (inwersja, liczba mnoga i rezygnacja ze zdrobnienia) w stosunku do znanego sformułowania sprawiają, że opresyjny charakter zostaje nieco zatarty.

W Klatce $z$ ptakami autor wprost nie wyraża krytycznego stosunku do krat, ale sam wiersz i jego tytuł domagają się dziś krytycznej lektury. Bardziej zdecydowaną postawę reprezentuje Ratajczak w Orle:

W tej klatce,

Kto by zgadł,

wysoko na gałęzi

przysiadł związany

wiatr.

Wicher o skrzydłach podciętych,

cyklon z wysokich gór. 
Kto nie poznał go wcześniej,

nie usłyszy jego szumu

zerwanych do lotu

piór.

Opresję, jaką jest klatka, autor ukazał w metaforze związanego wiatru i jego podciętych skrzydeł. To najbardziej poetycki obraz w twórczości dla dzieci Ratajczaka przedstawiający zoo jako miejsce, w którym człowiek nie może zobaczyć zwierzęcia takim, jakie ono jest w rzeczywistości.

Porównanie obu wierszy pozwala wyciągnąć jeszcze jeden wniosek. Razi zamknięcie dużego ptaka, bo całkowicie uniemożliwia mu to czynności, które budzą w człowieku zachwyt. Gdy mowa o małych, nie jest to już takie oczywiste. Trudniej więzić silnego i dumnego ptaka, ale widok w klatkach delikatnych i bezbronnych nie wzbudza już takiego zdziwienia - wciąż mogą śpiewać dla przyjemności ludzkiego ucha. Poezja dla dzieci Ratajczaka to mały krok w sprawie literackiej emancypacji zwierząt. Jeszcze wiele pozostało do wykonania.

W kilku utworach autor tematyzuje motyw ucieczki z zoo. By jej dokonać, zwierzęta wiedzą, że muszą zrezygnować z cech przypisanych ich gatunkom na rzecz ludzkich przyzwyczajeń - stanąć na dwóch łapach/nogach (Lew w śródmieściu) czy przebrać się za człowieka. Tego drugiego sposobu próbuje żyrafa (Kłopoty $\dot{z} y r a f y$ ), przeszkadza jej jednak długa szyja. Płynie stąd gorzkie przekonanie, że to, co specyficznie żyrafie, determinuje konieczność życia w niewoli.

Opis ucieczki lwa otwiera jeszcze jeden temat opresyjnego stosunku człowieka do zwierzęcia - futra i skóry jako ubrań dla człowieka. Lew w śródmieściu ${ }^{6}$ rozpoczyna się od takiego obrazu:

Lew stanął na dwóch łapach,

rozczesał brodę, futro pod szyją zapiął,

otworzył klatkę i raźno

ruszył przez ZOO na miasto.

(...)

Szeptano wokół: Atleta!

Co za futro kosztowne! Jakie rękawiczki!

Ludzie, których spotyka lew, zgodnie z prawem konwencji nie widzą w nim lwa przebranego za człowieka, ale kawałki ubrań. Gdy zwierzę udaje człowieka (by zyskać wolność), futro nie leży już na nim naturalnie. Teraz można je zapiąć pod szyją, jakby było tylko ubraniem, a nie integralnym elementem ciała. Paradoksalnie, polowania na lwy nie mają ścisłego związku z przemysłem odzieżowym. To wyłącznie trofeum, zdobycz, dowód zdominowania dzikiego zwierzęcia. Ratajczak posługuje się ogólnym, wyobrażeniem ludzi na temat jednego ze sposobów wykorzystania futra. Jednak by dostrzec nieoczywistość tej sytuacji, potrzebny jest moment refleksji

\footnotetext{
${ }_{6} \quad$ W wersji z Między nami zwierzakami pod tytułem Lew na przechadzce.
} 
związany z samym celem polowań na lwy i antropocentrycznymi skojarzeniami dotyczącymi przeznaczenia zwierząt.

Wzmianka o futrze pojawia się także w dziwnej i smutnej Kołysance dla zwierzat. Zimowy sen chroni przed przemocą człowieka, z woli którego zajączek stanie się pasztetem, lisek - futrem, a miś zostanie nauczony sztu-

czek. Świat przyrody śpiewa im kołysankę, człowiek jest intruzem, który niszczy prawdziwą harmonię. W wierszu nie mówi się o zającu, lisie czy niedźwiedziu, formy nieco zinfantylizowane służą okazaniu czułości.

W Wycieczce do zoo znajdujemy także obraz zwierzęcia pogodzonego z życiem za kratkami (Tygrys). Nim poeta przejdzie do przedstawienia tygrysa, który spokojnie leży, patrzy na ludzi, nie może porozumieć się z lwem (bo ten nie włada językiem tygrysim), ale pokornie czeka na kolację, ujawnia się wprost jako ten, kto mówi: „Wymyśliłem taki rym do słowa tygrys: / wygryzł”. W ten sposób już od samego początku wiemy, że tak naprawdę nie o zwierzę tu chodzi, ale o językową zabawę człowieka, której przedmiotem stał się tygrys.

Jest jeden wiersz, Maleńkie zoo, w którym poeta, w sposób dla mnie zupełnie niezrozumiały, do zoo porównuje łąkę (używając także słowa „zwierzyniec”). Ten mikroświat, ekosystem, Ratajczak przedstawił niejako pod lupą. W ludzkiej optyce każdy może być w nim kimś innym, większym: jaszczurka - krokodylem, wróbel - orłem, mysia norka - jaskinią lwa. Oko człowieka wartościuje i pewne gatunki stawia na pozycji uprzywilejowanej, do której się aspiruje. Pierwszym pytaniem jest zasadność porównania dwóch przestrzeni, które posiadają tak różne kulturowe znaczenie. Łąka (w polskiej tradycji przede wszystkim Leśmianowa) kojarzy się raczej z wolnością, z brakiem ograniczeń, zoo - przeciwnie, jest znakiem zniewolenia i opresji. To pokazuje, jak trudne, pełne pułapek (klatek), pozorów i kulturowych konstruktów jest myślenie o ogrodzie zoologicznym.

Nie bez żalu trzeba przyznać, że do zoo dzieci bywają prowadzone także przez poetów, nie tylko przez Ratajczaka. Pisał o tym także jeden z najważniejszych architektów zbiorowej wyobraźni związanej z poezją dla dzieci - Jan Brzechwa. Jego czterowiersze o zwierzętach należą do najpopularniejszych wierszy kierowanych do młodych czytelników.

\section{Szukanie zwierząt}

Berger pisał, że ludzie nie mogą porozumieć się ze zwierzętami, ponieważ nie mają wspólnego języka. Ludzkie zwierzę zamiast spotkać się z przedstawicielami innych gatunków, panuje nad nimi - może je oswoić, ale także wykorzystać do pracy lub zjeść (Berger 1999, 11-12). To stwierdzenie nie tyle pokazuje całkowity brak możliwości spotkania, co raczej wskazuje kierunek ruchu, który powinien wykonać człowiek, by móc rzeczywiście zbliżyć się do zwierzęcia. Tym działaniem jest próba rezygnacji ze swojej władzy nad innymi gatunkami, a zarazem otwartość na ich 
sposoby komunikacji z człowiekiem. Dramat braku porozumienia ukazał także Ratajczak w wierszu Mowa zwierzat:

Ptak śpiewa drzewom na ucho...

Co śpiewa? Nie wiem. Jestem głuchy.

Dzięcioł przez cały dzień rozmawia z pniem.

O czym? Powiedzieć nie umiem.

Nic z tego nie rozumiem.

Lew ryczy, mruczy miś, huczy sowa...

Do kogo, pytam, ta mowa?

I martwię się ogromnie.

Bo chyba mówią do mnie?

Dziwią się i bardzo się boją, że choć widzę i słyszę -

nie mogę jakoś ich pojąć.

W Pożegnaniu baśni, jednym z najważniejszych i najpopularniejszych wierszy autora o kresie dzieciństwa, dowiadujemy się m.in. wtedy, gdy przestajemy wierzyć, że zwierzęta mówią. Pierwsze lata życia to także czas, kiedy żywa jest wiara w to, że mają one coś do przekazania. Nie daje to jednak, jak wydaje się dorosłemu poecie, gwarancji porozumienia. W Mowie zwierzą warto zwrócić uwage przede wszystkim na zarysowaną postawę podmiotu. Człowiek uznaje swoje ograniczenia, a jednocześnie prezentuje zdecydowanie antropocentryczną postawę, która pomija inne niż ludzki sposoby porozumienia. Jest $\mathrm{w}$ tym pewien paradoks otwartości i rezygnacja w relacji ze zwierzętami. Może więc jednak wszystko to nie dotyczy wyłącznie wieku, ale wyobraźni (i wiary w nią), która jest sprawą empatii i umożliwia międzygatunkowe porozumienie.

Przytaczam także wcześniejszą redakcję omawianego wiersza z Między nami zwierzakami, opublikowaną pod tytułem Rozmowa, różniącą się kilkoma frazami i ostatnią strofą:

Ptak mówi mi na ucho,

ale jestem głuchy.

Dzięcioł przez cały dzień stuka we mnie jak w pień.

Komar bzyka, jak umie, nic z tego nie rozumiem.

Lew ryczy, muczy krowa, do kogo, pytam, ta mowa?

Do kogo kot miauczy co dzień?

A może nie o mnie tu chodzi?

Zmartwiłem się ogromnie. Wolałby, żeby szło o mnie. 
Ale najwięcej wie wietrzyk

o piórkach,

jednak milczy w najlepsze,

jak wielbłąd i wiewiórka.

Różnicę można dostrzec już w pierwszych dwu wersach. Początkowo ptak próbował skomunikować się z tym, kto mówi w wierszu. W drugiej wersji to człowiek przypatruje się przyrodzie, z którą stracił kontakt. Można zauważyć jeszcze jedno przesunięcie. Najpierw człowiek stawia w centrum siebie. Choć nie rozumie mowy świata (najpierw głosów poszczególnych zwierząt, później abstrakcyjnego wiatru), ma nadzieję, że wszyscy wokół się nim interesują, uznają jego obecność. W późniejszej wersji nie zakłada już, że to przyroda wykonuje krok ku niemu, ale ma świadomość, że on sam nie umie się do niej zbliżyć. I tym razem okazuje się, że brakuje tylko jednego kroku, gestu wyobraźni, która otworzy na to, co wykracza poza język człowieka, wymaga zaangażowania i otwartości, a to umożliwi komunikację.

Barierą utrudniającą spotkanie człowieka i zwierzęcia są także stereotypy charakterystyczne dla ludzkich wyobrażeń na temat innych gatunków. Niektóre z nich można zdemaskować, czytając wiersze Ratajczaka o zoo, np. Nasza IV b w zoo. Przybyłe do ogrodu zoologicznego dzieci postępują zgodnie z przekonaniami (zaszczepionymi przez dorosłych?). Nieadekwatność wcześniejszych wyobrażeń o rzeczywistości ilustruje doświadczenie Benia chce on podeprzeć żyrafie szyję dwoma kijami i jest bardzo zdziwiony, że ta doskonale sobie radzi bez jego pomocy. Zaskoczenie chłopca to zdumienie dziecka, które spotkało żywe zwierzę, nie to z obrazka, z książki dla dzieci czy infantylizujących i niemądrze antropomorfizujących opowieści dorosłych. W tej sytuacji zoo staje się miejscem obnażania stereotypów. Nie zmienia to jednak faktu, że między innymi ogrody zoologiczne, a wcześniej zwierzyńce i menażerie sprawiły, iż człowiek nadał sobie realną i symboliczną władzę, także związaną z konstruowaniem obrazów i wyobrażeń na temat zwierząt.

Niektóre wiersze dla dzieci Ratajczaka posługują się także stereotypami i cechami zwierząt, wyostrzonymi przez dorosłych - i tak osioł jest uparty (Uparty osioł), niedźwiedź śpi (Porachunki z niedźwiedziem), lis jest chytry (Lis z komisu), wielbłąd, z założenia czy raczej z (fałszywej) etymologii, robi dużo błędów (Wielbłąd $w$ urzędzie), a jeż jest ciągle zdenerwowany, bo się jeży (Jeż). Nawiązuje do tej konwencji/tych zabiegów także wiersz Jak jest i dlaczego?, w którym w usta zwierząt wkłada się ludzkie przekonania na ich temat. Pies mówi (sic!), że wszystko jest pod psem, zebra widzi świat w paski, flądra - mokry i płaski.

Utwory, których humor jest oparty na cechach fizycznych zwierząt lub wiąże się z kulturowo przypisanymi im cechami, są popularne nie tylko w wierszach Ratajczaka, ale także innych autorów poezji dla dzieci. To chyba najmniej twórcze i zdecydowanie opresyjne podejście do zwierzęcych bohaterów. W ten sposób pozaludzki bohater zostaje zamknięty w ciasnej klatce wyobrażeń, alegorii i stereotypów przypisanych mu przez człowieka. 
Stąd już blisko do cyrku w poezji dla dzieci, który tu rozumiem metaforycznie jako przypisywanie zwierzętom cech lub stawianie ich $\mathrm{w}$ zupełnie przypadkowych sytuacjach, które mają, w prosty sposób, wywołać śmiech dziecięcego odbiorcy.

Szukanie zwierząt $\mathrm{w}$ poezji Ratajczaka odbywa się na jeszcze jednym poziomie, w języku, w lingwistycznych grach ze zwierzętami. Ich główną zasadą jest brzmieniowe podobieństwo słów. Takich wierszy w twórczości poety znajdziemy sporo. Nawiązują do tego np. Pytania bez odpowiedzi („Czy mysz / jest w mysikróliku?” „Co okoń ma do konia?”), Słoń i słońce oraz w Lew $w$ telewizorze, w których zależność między słowami widoczna jest już w tytule.

Jednym z ciekawszych przykładów takiej zabawy jest Lisi alfabet. Do tytułowego zbioru należą tylko trzy głoski l-i-s, eksponowane także jako litery, ponieważ poeta zwraca uwagę również na ich kształt graficzny:

LIS wciąż chodzi koło drogi,

chodzą pod nim lisie nogi.

Najpierw dwie, a potem cztery -

Równe, proste jak litery.

L - to noga co się skrada,

I - gdy w biegu ponad ziemią,

S - to ogon bardzo ładny...

I już w LISie liter nie ma.

Bo LIS w trzech literach mieszka i roznosi je po ścieżkach.

Tutaj L, tam I postawi,

$S$ napuszy dla zabawy.

A gdy i

zamienisz $\mathrm{w}$ a,

LIS

Ucieknie zaraz

w LAS.

W pierwszej wersji z Między nami zwierzakami ostatnia część wiersza była nieco bardziej statyczna: „Lub litery wszystkie zbierze / i jak myślnik zacznie leżeć".

Formalne zabawy w tym przypadku nie są sposobem zrozumienia zwierzęcia. Te zwierzęta-słowa całkowicie należą do człowieka i słychać tu wyłącznie jego głos.

Choć nie wprost, antropocentryczne spojrzenie Ratajczak demaskuje $\mathrm{w}$ Łabędziu:

Ma tylko łabędzią szyję,

a wszystko inne czyjeś:

pióra - gęsie,

lapy - kacze,

Z dziobem jest też nie inaczej.

Polonistyka. Innowacje 
Obnosi więc szyję swą wszędzie

i to nie dołem, lecz górą,

by nie okazać się

$$
\begin{aligned}
& \text { kaczką, } \\
& \text { gęsią } \\
& \text { ani kurą, }
\end{aligned}
$$

ale wyłącznie - łabędziem.

Przynależność „wszystkiego innego”, poza szyją, do różnych zwierząt nie dotyczy praw rządzących światem przyrody, a interpretacji tego, kto usiłuje tej rzeczywistości nadawać znaczenia. Choć poeta nie unika pułapki zwierzęcej synekdochy (szyja - łabędź), to próbuje stanąć po stronie istoty zamkniętej w schematach ludzkich skojarzeń. W ten sposób autor wychyla się z antropocentrycznego punktu widzenia, szuka innej możliwości, dzięki czemu dostrzega jednostkę, jeden gatunek, nie wyłącznie gotowy system wyobrażeń o zwierzętach. Takie spojrzenie może być odczytane także jako przejaw wrażliwość na obecność zwierząt, a to wymaga uważności i krytycznej refleksji nad sposobem myślenia człowieka funkcjonującego w kręgu kultury europejskiej.

\section{Perspektywa w stanie podejrzenia}

Omówione przeze mnie wiersze umieszczone w Między nami zwierzakami oraz w Wycieczce do zoo nie są jedynymi utworami Ratajczaka dla dzieci, w których pojawiają się zwierzęta. Tacy bohaterowie widoczni są wielu książkach autora. Lektura Wiatru-ptaka czy Gila pozwala się przekonać, że poetyckie przedstawienia istot żywych innych niż człowiek u tego poety wiążą się nie tylko $\mathrm{z}$ opresją, ale także wrażliwością i metaforą.

Być może trzeba uznać, że o zwierzętach „na wolności” (nie w zoo) pisze się łatwiej. Czy ma na to wpływ brak tak obciążenia etycznego za niewolę zwierząt u tych, których reprezentantem jest autor? Poezja i wyobraźnia potrzebują wolności, domagają się wolności i chcą mówić w jej imieniu. Jeśli tak jest, są narzędziem emancypacji zwierząt w literaturze. Może jednak poeta po prostu nie miał głębszej refleksji nad zoo jako realnym miejscem i tematem kultury, dlatego jego teksty oscylują między empatią względem zwierząt a usprawiedliwieniem (choćby tylko w języku, jak np. W małym zoo) działań człowieka.

Jednak właśnie to narracja o grodzie zoologicznym skłania do refleksji nad głosem i losem zwierzęcia. Próby uwolnienia się z zoo kończą się porażką nie dlatego, że żyrafa ma za długą szyję, a lew zjadł cały asortyment sklepu mięsnego. Zwierzęta pozostają w niewoli antropocentrycznego oka, oka człowieka dorosłego. Nadzieję dla nich stanowi wrażliwość dziecka. Jednak ona także od kogoś zależy, zostaje więc w ten sposób zniewolona.

Rozpoznania prowadzone $\mathrm{z}$ perspektywy studiów nad zwierzętami wymagają ciągłej podejrzliwości, nieustannego sprawdzania i podważania głosu autora/autorki, ale także ciągłej autorefleksji badacza, badaczki nad 
własnym językiem odnoszącym się do zwierząt. Konieczność wzbudzania w sobie takiej postawy jest potrzebna także w badaniach związanych z literaturą czy szerzej, sztuką dla dzieci. Swój głos, swoją perspektywę w stan podejrzenia musi stawiać każdy i każda, kto pisze o dzieciach jako bohaterach i odbiorcach różnych tekstów kultury.

\section{Bibliografia}

Berger John, 1999, Po cóż patrzeć na zwierzęta, w: O patrzeniu, Sikora S. (przeł.), Warszawa.

Kostecka Marianna, 2007, Wycieczka do zoo „Czas Kultury”, nr 6.

Ratajczak Józef, 1971. Między nami zwierzakami, Kraków.

Ratajczak Józef, 1982, Wycieczka do zoo, Poznań.

Ratajczak Józef, 1986, Rewolucja przyimków, „Sztuka dla Dziecka”, nr 1.

Ratajczak Józef, 1987, Małe Credo, „Sztuka dla Dziecka”, nr 6(7).

Ratajczak Józef, 1987, Poeci - dzieciom, „Sztuka dla Dziecka”, nr 3(4).

Rąbkowska Ewelina, 2016, „Śmieciowe” zwierzęta (trash animals) $i$ „dzieci śmieci". Relacja dziecka i zwierzęcia w literaturze dla dzieci i młodzieży, w: Mik A., Pokora P., Skowera M. (red.), Czytanie menażerii. Zwierzęta $w$ literaturze dziecięcej, młodzieżowej i fantastycznej, Warszawa.

Skowera Maciej, 2016, Literackie spotkania istot podporzadkowanych. Studium przypadku: „Miasteczko ostatnich westchnień” Grzegorza Gortata, w: Mik A., Pokora P., Skowera M. (red.), Czytanie menażerii. Zwierzęta w literaturze dziecięcej, młodzieżowej i fantastycznej, Warszawa.

Szymborska Karolina, 2014, W laboratorium children studies. Dziecko i dzieciństwo w nowym dyskursie, w: Niesporek-Szamburska B., Wójcik-Dudek M. (red.), Nowe opisanie świata. Literatura i sztuka dla dzieci i młodzieży w kręgu oddziaływań, Katowice.

Świtek Gabriela, 2007, Dział zwierząt, „Czas Kultury”, nr 6.

Waksmund Ryszard, 2000, Od literatury dla dzieci do literatury dziecięcej (tematy - gatunki - konteksty), Wrocław.

Waksmund Ryszard,1986, Od poezji dydaktycznej do liryki dziecięcej, w: Żurakowski B. (red.), Poezja dla dzieci. Mity i wartości, Warszawa.

\section{O Autorce:}

Joanna Żygowska - doktorantka na Wydziale Filologii Polskiej i Klasycznej UAM, absolwentka polonistyki i teatrologii oraz podyplomowych studiów Literatura i Książka dla Dzieci i Młodzieży wobec Wyzwań Współczesności na UW. Zajmuje się literaturą dla młodych czytelników, przede wszystkim poezją, oraz teatrem dla dzieci i młodzieży. Pracuje w Teatrze Fredry w Gnieźnie jako pedagożka teatru, koordynuje Obserwatorium Sztuki dla Dziecka w Centrum Sztuki Dziecka w Poznaniu. 
